\title{
Intercropping Cedrela odorata with Shrubby Crop Species to Reduce Infestation with Hypsipyla grandella and Improve the Quality of Timber
}

\author{
Carola Paul and Michael Weber \\ Department of Ecology and Ecosystem Management, Center of Life and Food Sciences Weihenstephan, Institute of Silviculture, \\ Technische Universität München, Hans-Carl-von-Carlowitz-Platz 2, 85356 Freising, Germany
}

Correspondence should be addressed to Carola Paul; paul@forst.wzw.tum.de

Received 27 November 2012; Accepted 14 December 2012

Academic Editors: D. Czeszczewik, M. Kitahara, G. Martinez Pastur, and S. Riffell

Copyright (C) 2013 C. Paul and M. Weber. This is an open access article distributed under the Creative Commons Attribution License, which permits unrestricted use, distribution, and reproduction in any medium, provided the original work is properly cited.

Cultivation of Cedrela odorata, a valuable tropical hardwood species, is restricted by the mahogany shoot borer (Hypsipyla grandella), whose attacks reduce stem quality in forest plantations. This study investigated whether infestation rates would be reduced and growth performance improved by the intercropping of $C$. odorata tree seedlings with different crop rotations. The height increment achieved by $C$. odorata during the first two years was significantly stimulated by the intercropping of maize (Zea mays), pigeon pea (Cajanus cajan), and cassava (Manihot esculenta). Attacks of H. grandella were also considerably reduced in these treatments, compared to the control plots, while intercropping with beans and rice produced no improvement. The effect was particularly distinct when lateral competition between trees and crops was high. Accordingly stem quality was higher in the treatments featuring tall crops. Trees intercropped with C. cajan performed best in terms of height $(276 \mathrm{~cm} \pm 93)$, survival (100\% \pm 0 ), and quality $(81 \% \pm 13.5$ of trees with satisfying stem quality) after two years. We concluded that intercropping of tree seedlings which are susceptible to $H$. grandella with shrubby multipurpose species can improve both tree growth and timber quality and hence increase the attractiveness of such species for reforestation.

\section{Introduction}

Cedrela odorata L., a member of the family Meliaceae, is valued on international markets for its attractive wood. Native to most of Central America, it is now widespread throughout subtropical and tropical life zones [1-3]. Despite its wide native range, individuals are not very common in natural forests and are mostly scattered in mixed semievergreen or semideciduous forests dominated by other species [4]. Due to extensive timber extraction and poor natural regeneration [5], the species is now considered to be endangered in Mesoamerica [6]. However, the demand for the wood, sold under the commercial name "Spanish Cedar," remains high. Similar to other species of the Meliaceae family, such as Swietenia macrophylla King, the wood is both rot and termite resistant, which, along with its light weight (specific gravity of 0.4 [7]), makes it highly suitable for exterior constructions.
Due to its high strength, easy workability, and its low and even shrinkage, it is also frequently made into veneer and used for furniture and interior fittings [8,9]. Additional characteristics-among others, the medicinal value of the bark-make it a desirable multipurpose tree species [9]. In spite of the high demand for its wood, however, $C$. odorata is rarely used in reforestation projects or commercial plantations due to low planting successes in the past $[3,9]$.

In Central America, the main obstacle is the high susceptibility of $C$. odorata (along with other species of the Meliaceae family) to attack by the mahogany shoot borer (Hypsipyla grandella Zeller). This insect is a small moth (Pyralidae) that bores into the pith of terminal shoots, ultimately resulting in multiple shoot growth and forked trunks of little economic value [10]. Once a plantation is invaded by the insect, nearly all trees are attacked, thus rendering the production of Meliaceae hardwoods in pure stands too risky. 
Hence, considerable research has been carried out to reduce Hypsipyla infestation. For example, much effort has been spent on the development of viable insecticides [11], pestresistant planting stock $[6,12,13]$, and on the introduction of parasitoids, predators, or viruses [14]. Yet, up to now, none of these methods have proved effective in preventing damage [14]. Consequently, it is widely acknowledged that a significant reduction in mortality can be achieved only by combining these measures with silvicultural management options, such as admixing with other tree species, in order to reduce the density of potential host trees $[6,9,15,16]$. In Central America, $C$. odorata is therefore frequently used and promoted, for example, as a shade tree in agroforestry systems alongside coffee $[17,18]$ or cacao $[19,20]$, in pastures [9], and in living fences $[21,22]$. These systems might not, however, be able to tap the full potential of this tree species and might not provide either the quality or the quantity of wood demanded. Due to lack of knowledge about native hardwood species, exotic tree species are generally used for large-scale reforestation in Central America. In Panama, for example, where the present study took place, $82 \%$ of the reforested area is planted in nonnative species such as Tectona grandis, Pinus caribaea, and Acacia mangium [23]. However, studies have shown that native tree species might be better able to restore degraded land, fulfill multiple purposes, and at the same time, be equally attractive in terms of financial returns [24-26].

Given the scarcity of $C$. odorata in natural forests and the high demand for its wood, the objective of the present study was to test new management options to successfully include C. odorata in forest plantations to meet this demand, while reducing logging pressure on remnant natural forests and ensuring the preservation of the species. As noted above, agroforestry systems have already been considered as a possible option for integrating $C$. odorata into the landscape. It is widely acknowledged that such land-use systems can help to enrich the ecological value of the landscape $[27,28]$, improve the economic situation of farmers $[29,30]$, and also contribute to food security. Moreover, studies have shown that lateral competition in agroforestry systems can improve growth and quality of $C$. odorata $[6,19]$. However, rather than using the species for scattered shade trees between crops or in pastures, the approach of this study was to create a fully stocked forest plantation of $C$. odorata with the purpose of sawn wood production with a typical tree density for tropical forest plantations [31]. During the first two years after plantation establishment, trees were enriched by different agricultural crops. The system of planting mostly staple food crops between young tree seedlings is well known under the name "Taungya" and originates from southeast Asia [32]. It has been applied throughout the tropics, including Central America $[33,34]$. Studies with S. macrophylla in Belize and Puerto Rico have shown that this agroforestry system might help to overcome the difficult initial growth phase where plantations are most susceptible to $H$. grandella infestation $[35,36]$.

For this study we hypothesized that intercropping of $C$. odorata would reduce $H$. grandella infestation and at the same time improve both growth performance and timber quality.
Four intercropping treatments including different staple food crops were tested and compared to pure C. odorata stands.

\section{Materials and Methods}

2.1. Study Area. The experimental site is located near the town of Tortí, at the border of the Provinces of Panama and Darien in the eastern part of the Republic of Panama $\left(9^{\circ} 86^{\prime} 30^{\prime \prime} \mathrm{N}, 79^{\circ} 93^{\prime} 20^{\prime \prime} \mathrm{W}\right)$. The elevation is 119 meters above sea level, and the mean annual temperature is $26.4^{\circ} \mathrm{C}$ [37]. Mean annual precipitation is $1910 \mathrm{~mm}$, with a dry season between January and March with less than $30 \mathrm{~mm}$ of monthly rainfall [37]. The study site is characterized by Vertisols, with a clayey texture featuring the typical formation of mounds and depressions known as "Gilgai," that develop due to the shrinking and swelling of the soils [38]. With the exception of these differences in the microrelief, the experiment was established on a plain. The land-use history of this region is relatively young, with intensive conversion of previously undisturbed tropical rainforest into farmland beginning in the 1970s [39]. The experimental site itself was used for several years as cattle pasture, but today it is owned and used as a commercial forest plantation by the Forest Finance Group. In August 2009, twenty plots of $200 \mathrm{~m}^{2}$, each containing 16 C. odorata seedlings, were established within an area of 3.7 hectares. One of five treatments (to be described below) was randomly assigned to each of these plots and hence to 64 trees.

2.2. Intercropping Treatments. The four different intercropping treatments which were compared to pure $C$. odorata plantations without intercrop (FP) are displayed in Table 1. In two of these intercropping treatments different crops were planted in rotation, while in the other two only one crop was planted during the observation period of two years. In the M-B-M-M treatment common beans (Phaseolus vulgaris) were alternately planted with maize (Zea mays) to improve soil fertility. At the same point in time, beans were also planted in the B-R-R treatment previous to two consecutive rice rotations (Oryza sativa). This simultaneous planting of beans with and without previous maize harvest was done to enable comparison of the nutrient cycle between the two treatments (not discussed in this paper). In addition to the two grain/bean rotations, a commonly grown tuber crop-cassava (Manihot esculenta) — and a leguminous shrub-pigeon pea (Cajanus cajan)-were included in the experiment. Both are shrubs reaching heights of up to $3 \mathrm{~m}$. Pigeon pea is a common agricultural plant in Panama, as the peas are used for a traditional Christmas dish, and the leaves are used as fodder for cattle due to their high nutritional value and are also frequently processed to make medicinal ointments. These multiple purposes, along with its ability to fix nitrogen, make $C$. cajan a desirable plant for agroforestry systems $[28,40]$. Previous to the planting of pigeon pea, ginger (Zingiber officinale) was planted in these plots. However, as this crop did not germinate in the trial, the management in these plots can be considered as identical to that undertaken in the control plots (FP) during the first 
TABLE 1: Overview of the different crop rotations planted between C. odorata trees. Light shading indicates crops with a height of less than $1 \mathrm{~m}$, and dark shading indicates crops reaching a height greater than $2 \mathrm{~m}$.

\begin{tabular}{|c|c|c|c|c|c|c|c|c|c|}
\hline \multirow{4}{*}{ Treatment } & \multirow{4}{*}{ Abbreviation } & \multicolumn{8}{|c|}{ Calendar year, (calendar month), and month after tree planting } \\
\hline & & 2009 & & & & & & 2011 & \\
\hline & & {$[08-11]$} & {$[11-02]$} & {$[02-05]$} & [05-08] & {$[08-11]$} & {$[11-02]$} & {$[02-05]$} & [05-08] \\
\hline & & $0-03$ & 03-06 & $06-09$ & $09-12$ & $12-15$ & $15-18$ & $18-21$ & $21-24$ \\
\hline Maize-beans-maize-maize & M-B-M-M & Maize & Beans & & Maize & Maize & & & \\
\hline Beans-rice-rice & B-R-R & & Beans & & Rice & Rice & & & \\
\hline Cassava & C & & & & & & & & \\
\hline Ginger $^{1}$-pigeon pea & G-P & & & & & Pigeon pea & & & \\
\hline Forest plantation without intercrop & $\mathrm{FP}$ & & & & & & & & \\
\hline
\end{tabular}

Is not displayed, as seeds did not germinate.

9 months, and no further mention of ginger will be made in the discussion to follow.

2.3. Tree and Crop Management. The seedlings for the plantation were raised in the project's nursery, with the support of Brinkman y Asociados Reforestadores de Centro América, SA (BARCA SA). Seeds were collected from 5 mother trees in natural forests in the adjacent districts of Chepo and Chepigana. Before tree planting, tall grasses and woody successional vegetation were cleared manually and chemically using Glyphosate $\left(4 \mathrm{Lha}^{-1}\right)$. One week after planting, $20 \mathrm{~g}$ of 15-30-8 N-P-K fertilizer was divided among three holes placed at a distance of $15 \mathrm{~cm}$ from each tree. In the control plots, spot-ringed cleaning using a machete was applied to all trees every four weeks for the first four months. During the following months any regrowth of competing vegetation in these plots was cut back to the ground every four months. In the agroforestry plots, both manual and chemical weed control were carried out before crop sowing. No weeding had to be carried out during crop cultivation, as the crops rapidly shaded out grasses. In plots in which temporarily no intercrop was present (see Table 1), vegetation was cut every four months in accordance to the management.

Crops were planted starting two weeks after tree establishment (Table 1). Due to low precipitation, no intercropping was carried out during the dry season. In accordance with local agricultural practices [41], establishment and management of crops was carried out manually, and seeds for crops were obtained from local farmers. Cassava was cultivated using locally-acquired stem cuttings of $15-20 \mathrm{~cm}$ in length and a diameter of $2-3 \mathrm{~cm}$, also in accordance with local tradition. Planting distances for maize, beans, and rice were $30 \mathrm{~cm}$ within rows and 90,70 , and $30 \mathrm{~cm}$, between rows, respectively. Pigeon pea and cassava were both planted at $1 \times$ $1 \mathrm{~m}$ intervals. All crops were sown in a regular grid between trees, leaving a radius of $50 \mathrm{~cm}$ around each tree free of crops, thus creating very dense competition. To meet certification standards of the Forest Stewardship Council (FSC), no pesticides were applied [42], but the first and third maize rotations were fertilized using $180 \mathrm{~kg} / \mathrm{ha}$ of 15-30-8 NPK fertilizer.

2.4. Data Collection. Intercropping was carried out during the first 18 months after tree planting. During this time, the vegetative growth of trees was measured every three months (starting year 0 ). After 24 months, a final growth performance survey was done in order to evaluate possible long-term effects of intercropping. Height $(h)$ was measured as the shortest distance between the highest tissue in the canopy and ground level, as proposed by Cornelissen et al. [43]. Root collar diameter ( $\mathrm{rcd}$ ) was recorded $5 \mathrm{~cm}$ above ground level. Presence or absence of shoot borer attack was recorded every three months, and if damage was detected, infested parts were cut and burned. Also at three-month intervals, all trees were pruned to one apical shoot, to improve wood quality.

In the first three months after plantation establishment, we observed that the planting position relative to the microrelief strongly affected seedling development. While small depressions quickly filled with water during the rainy seasons, deep cracks developed during the dry season, making those planting positions unsuitable for tree seedlings. Therefore the planting position relative to the microrelief was noted, using the code 1 , for seedlings planted in depressions and 0 for seedlings on the flank or top of a mound. In addition, the quality of each tree was assessed and characterized as "bad" if the stem was forked or consisted of multiple stems.

2.5. Data Analysis. A general linear mixed model (LMM) was applied to compare tree growth (height and diameter) between treatments. Mixed models are frequently used in agricultural and forestry research, as they allow the inclusion of random environmental effects [44]. In this study, the mixed-model approach was used, as the assumption of independence of observations was violated due to the fact that trees are spatially clustered within plots. Therefore, plot number was included in the model as a random factor, allowing intercepts to vary across plots. The various intercropping treatments were included as a fixed factor with 5 levels and the microrelief for each tree as a binary covariable. The same model was applied to test for differences in the final status of tree traits between the different treatments after the entire 24 months, as well as at various different time periods. The latter approach facilitates the allocation of effects to certain crop rotations due to different planting and harvesting periods (Table 1). Furthermore, the nonlinear growth trajectories of the trees impeded the use of a mixed model for clustered longitudinal data which would assign an additional random 

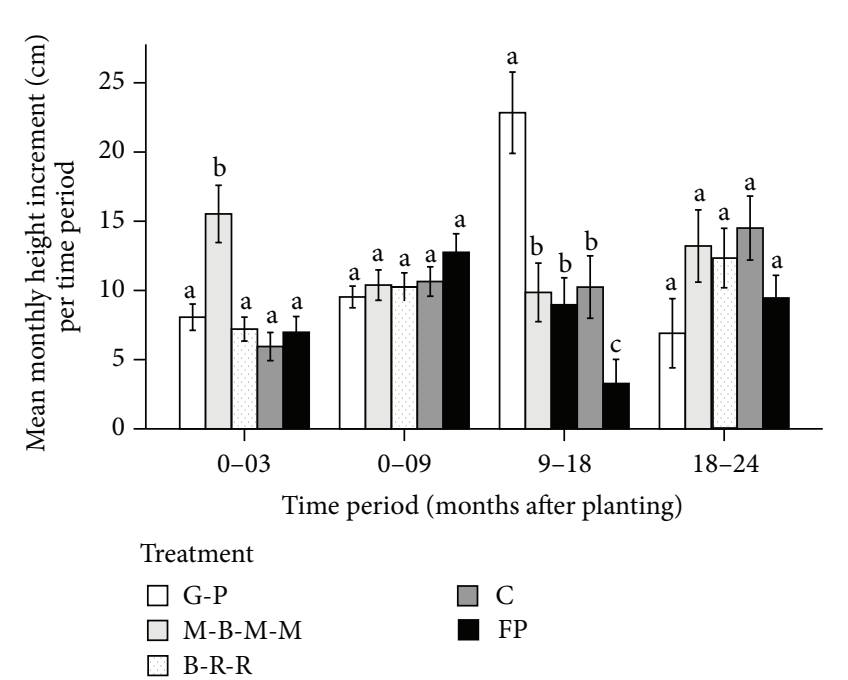

(a)

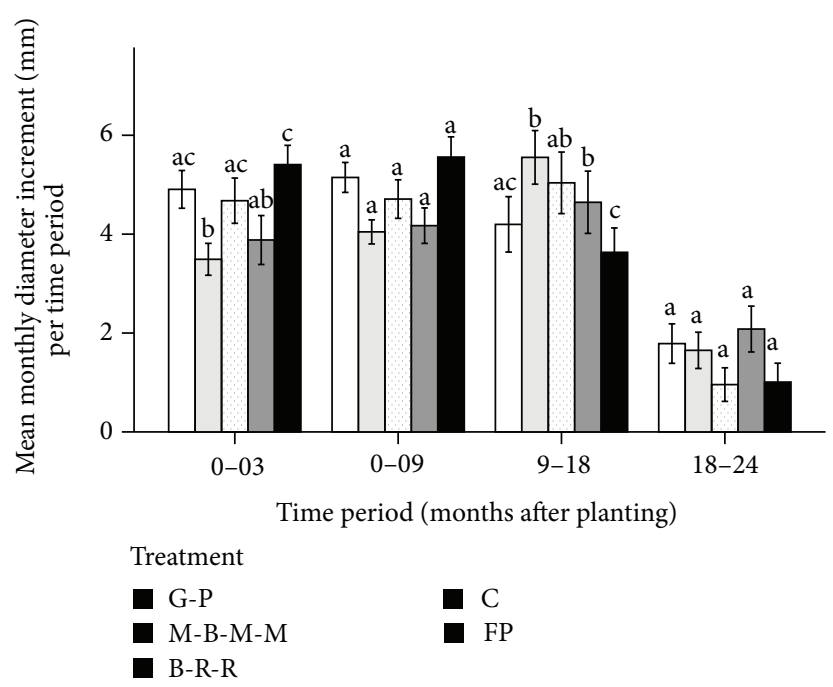

(b)

Figure 1: Height (a) and root collar diameter (b) increment per month during different time periods in different treatments. Different letters within each time period denote significant differences between treatments (LSD test: $P<0.05$ ). For abbreviations see Table 1.

time effect associated with both the intercept and slope (effect of time) to each tree (within plot), as they resulted in severe violations of model assumptions. The observation period was therefore split up into four periods for the purpose of analysis. The first three months were examined to investigate the initial growth phase of the trees. Next, the first 18 months, during which enrichment planting was carried out (including the previously examined initial three-month period), were divided into two time periods-before and after dry season-at 9 months. These intervals correspond to the main sowing and harvesting periods for all crops, with the exception of cassava (Table 1). Finally, the growth increment in the period between 18 and 24 months was analyzed in detail to investigate the development of trees after enrichment planting had stopped.

To achieve normality, all dependent variables were transformed using the natural logarithm. As the model is only composed of one random effect, a simple variance component matrix (with assumed independent random effects), which assigned a scaled identity structure to each of the random effects, was used. The Residual Maximum Likelihood Estimation (REML) was applied to estimate the covariance parameters because it produces unbiased estimates by taking into account the loss of degrees of freedom that results from estimating the fixed effects [45]. The Satterthwaite approximation was used to calculate the degrees of freedom, and Type III Sum of Squares was used to estimate fixed effects. The assumption of normally distributed residuals was checked using the Kolmogorov-Smirnov test. Other model assumptions (e.g., nonlinear patterns) were revised visually using Q-Q plots and scatter plots of conditional residuals plotted against predicted values. Pairwise comparisons using least significant differences (LSD) were used to test for significant differences among treatments when the result of the Type III test of fixed effects was significant. The analysis was carried out using the "MIXED" command of SPSS 20. Error probabilities below 5\% $(P<0.05)$ were accepted as statistically significant. In order to compare damages caused by $H$. grandella between trees grown under different treatments, an infestation rate was calculated as the quotient of trees with visible signs of damage divided by the number of trees alive per plot ( $N=4$ per treatment) and time period. Infestation rate was tested for differences between treatments using a Generalized Linear Model (GLM) with a binomial probability distribution and the logit link function. Fisher scoring was used for parameter estimation. The robust Huber/White/Sandwich method offered by SPSS 20 ("GENLIN" command) for estimating variance parameters was used [46]. Chi-square statistics for the fixed effect treatment were calculated using the Wald method. As the Wald test can be unreliable in small samples, a likelihood ratio statistic between the intercept only model and the full model (including treatment as a factor) was also carried out [46]. The same procedure was used to test for significant differences between treatments in both survival rate per plot and fraction of "bad quality" trees per plot.

\section{Results}

The height increment of $C$. odorata was significantly affected by intercropping during the period from $0-3$ months ( $F$ $(4 / 15.068)=6.375 ; P=0.003)$ and in the period from $9-18$ months $(F(4 / 15.079)=14.473 ; P<0.0001)$. Figure 1(a) reveals that the initial height growth in the first three months was higher in the maize fields compared to that found in all other treatments $(P \leq 0.03)$. This is likely due to the intense light competition within maize fields stimulating better height growth among the young tree seedlings. During subsequent time periods, however, this effect was no longer evident, with the M-B-M-M treatment showing a by trend 
TABLE 2: Height, root collar diameter, survival per plot, and rate of forked or multiple stem trees per plot (bad quality) of C. odorata, 24 months after planting in pure forest plantations (FP) or combined with intercrops (for abbreviations see Table 1). Standard deviations are given in brackets. Different letters within columns denote significant differences between treatments $(P<0.05$ based on LSD test for height and diameter and Wald confidence intervals for survival and bad quality rate, respectively).

\begin{tabular}{lccccccccccrrr}
\hline & \multicolumn{3}{c}{ Height $(\mathrm{cm})$} & \multicolumn{3}{c}{ Diameter $(\mathrm{mm})$} & \multicolumn{3}{c}{ Survival (\%) } & \multicolumn{3}{c}{ Bad quality (\%) } \\
\hline G-P & 276 & $(93)$ & $\mathrm{a}$ & 71 & $(20)$ & $\mathrm{a}$ & 100.0 & $(0.0)$ & $-{ }^{1}$ & 18.8 & $(13.5)$ & $\mathrm{a}$ \\
M-B-M-M & 244 & $(83)$ & $\mathrm{ab}$ & 72 & $(18)$ & $\mathrm{a}$ & 92.2 & $(6.0)$ & $\mathrm{a}$ & 22.1 & $(11.8)$ & $\mathrm{a}$ \\
B-R-R & 229 & $(62)$ & $\mathrm{bc}$ & 68 & $(16)$ & $\mathrm{a}$ & 96.9 & $(6.3)$ & $\mathrm{a}$ & 50.0 & $(12.5)$ & $\mathrm{bc}$ \\
C & 251 & $(76)$ & $\mathrm{ab}$ & 70 & $(20)$ & $\mathrm{a}$ & 96.9 & $(6.3)$ & $\mathrm{a}$ & 31.7 & $(17.8)$ & $\mathrm{ab}$ \\
FP & 190 & $(59)$ & $\mathrm{c}$ & 66 & $(17)$ & $\mathrm{a}$ & 98.4 & $(3.1)$ & $\mathrm{a}$ & 57.8 & $(18.7)$ & $\mathrm{c}$ \\
\hline
\end{tabular}

Excluded from the analysis because of missing events.

inferior overall height growth. In general, however, height increment after the first 9 months seemed not be influenced by intercropping $(F(4,14.789)=0.586 ; P=0.678)$. After 9 months, maize, rice, and pigeon pea were sown (May 2010), and cassava was harvested after 12 months. Between 9 and 18 months, a height increment of $137 \mathrm{~cm}( \pm 70.6)$ was recorded in the pigeon pea plots, a figure seven times higher than the increment during this period in the plots without intercropping $(\mathrm{FP})(P<0.001)$ and more than twice the increment acquired by the trees in the plots that received other agroforestry treatments $(P \leq 0.001)$. After 18 months, C. odorata in the pure forest plantation plots without crops (FP) showed a mean height of $134 \mathrm{~cm}( \pm 48)$, while heights in the agroforestry treatments ranged between $155 \mathrm{~cm}( \pm 51)$ (B$\mathrm{R}-\mathrm{R}$ treatment) and $235 \mathrm{~cm}( \pm 75)$ (G-P-treatment). During the last observation period (18-24 months) no agriculture was carried out between trees in any of the treatments. The increment of trees in the former pigeon pea fields decreased considerably after harvest, suggesting a growth-inducing effect of the leguminous shrubs. Differences in increments among the five treatments in the period from 18-24 months were not statistically significant, though they had a very small $P$ value $(F(4 / 15.266=2.994) ; P=0.052)$.

Diameter growth also differed significantly between treatments during the first 3 months $(F(4 / 14.925)=4.381$; $P=0.015)$ and again during the period from 9-18 months $(F(4 / 15.223)=5.719 ; P=0.005)$. However, height and diameter growth were inversely related, suggesting that trees competing for light and space with crops show reduced diameter growth in favor of height growth (Figure 1(b)). This effect was particularly evident for trees growing in maize or pigeon pea fields. In contrast to these treatments, diameter growth was highest during the first 9 months in the FP, BR-R, and G-P plots where-at this time-no crops or only low-growing crops were planted between trees. However, in the subsequent months, control plots showed a surprisingly small diameter increment compared to agroforestry plots. Thus, growth performance was better in agroforestry plots compared to control plots in terms of both height and diameter increment.

After two years-that is, six months after the last crop harvest-tree height still differed among treatments $(F(4 / 15.050)=4.82 ; P=0.011)$. Trees in agroforestry treatments were still taller than those in pure forest plantation
(FP) with the exception of those in the B-R-R treatment (see Table 2). Greatest height was observed in G-P treatment, followed by $\mathrm{C}$ treatment. Both accompanying crops (pigeon pea and cassava) are shrubs which create a dense lateral competition. Root collar diameter hardly differed between treatments (see Table 2) $(F(4 / 14.812)=1.767 ; P=0.189)$ but also tended to be lowest in the FP and B-R-R plots.

Microrelief played an important role in the growth of C. odorata. Trees planted in relative depressions were generally associated with smaller diameters (estimated regression coefficient $b$, ranging between -0.091 and -0.152 with $P<$ $0.001)$ and smaller heights $(b$ ranging between -0.151 and -0.202 with $P \leq 0.006$ ) during all time intervals, with two exceptions. Relative planting position in microrelief did not affect height increment between 9 and 18 months $(b=-0.079$; $\mathrm{SE}=0.057 ; P=0.169)$ and between 18 and 24 months $(b=$ $0.024 ; \mathrm{SE}=0.056 ; P=0.669)$. At 24 months, both height and diameter were negatively influenced by a planting position in a relative depression $(h: b=-0.11 \mathrm{SE} 0.03 ; P<0.001 ; \mathrm{rcd}: b=$ -0.089 SE $0.027 ; P=0.001$ ).

Overall survival rate for all treatments was high: $97 \%$ of the 320 planted trees survived during the first two years, and in the pigeon pea plots, not a single tree died during this time. As the logit link function generally encounters severe problems when no event (in this case death of tree) occurs, and this treatment was excluded from the GLM, which revealed that survival rate between the other treatments did not differ significantly (Likelihood-Ratio-Test between intercept only model and full model: Likelihood-Ratio-ChiSquare $=3.461 ; \mathrm{df}=3 ; P=0.326$; fixed effect of treatment: Wald-Chi-Square $=3.307 \mathrm{df}=3 P=0.347$ ).

The first damage from $H$. grandella which we observed was found six months after planting when tree height of C. odorata ranged between 31 and $144 \mathrm{~cm}(\bar{h}=71 \mathrm{~cm} \pm$ 20.7). The H. grandella population increased between 6 and 9 months during the first dry season (Figure 2). Despite intensive management to control $\mathrm{H}$. grandella, infestation rates continued to increase between 9 and 12 months. At six months, $59 \%$ of all C. odorata trees in the trial were infected and at 12 months $70 \%$. In the following time intervals, abundance of $H$. grandella was generally reduced due to the onset of the rainy season. Infestation rates decreased to $27.5 \%$ during the period from 12 to 15 months. However, when trees were measured after a period of 6 months without intensive 
TABLe 3: $P$ values $(P)$ estimated by the Wald-Chi-Test to test for differences in the fraction of infested trees per plot between pairs of treatments within each time period. Tests were carried out using simple contrasts. Significant results with $P>0.05$ are presented in bold. $\operatorname{Exp}(\beta)$ can be interpreted as the odds of being infected by $H$. grandella compared between treatment 1 and treatment $2(\operatorname{Exp}(\beta)=$ odds of tree being infected in treatment 2 /odds of being infected in treatment $1 ; N=4$ per treatment and time period). For abbreviations see Table 1.

\begin{tabular}{|c|c|c|c|c|c|c|c|c|c|c|c|c|c|}
\hline \multirow{2}{*}{\multicolumn{2}{|c|}{$\begin{array}{l}\text { Age (months) } \\
\text { Treatment } 1^{1} \text { versus treatment } 2\end{array}$}} & \multicolumn{2}{|r|}{6} & \multicolumn{2}{|c|}{$6-9$} & \multicolumn{2}{|c|}{$9-12$} & \multicolumn{2}{|c|}{$12-15$} & \multicolumn{2}{|c|}{$15-18$} & \multicolumn{2}{|c|}{$18-24$} \\
\hline & & $P$ & $\operatorname{Exp}(\beta)$ & $P$ & $\operatorname{Exp}(\beta)$ & $P$ & $\operatorname{Exp}(\beta)$ & $P$ & $\operatorname{Exp}(\beta)$ & $P$ & $\operatorname{Exp}(\beta)$ & $P$ & $\operatorname{Exp}(\beta)$ \\
\hline \multirow{4}{*}{$\mathrm{G}-\mathrm{P}^{2}$ versus } & $\mathrm{FP}$ & 0.36 & 1.76 & 0.26 & 0.61 & 0.11 & 2.74 & 0.00 & 10.31 & 0.00 & 5.80 & 0.37 & 3.10 \\
\hline & $\mathrm{C}$ & 0.35 & 0.58 & 0.01 & 0.37 & 0.44 & 0.64 & 0.06 & 3.55 & 0.00 & 9.98 & 0.33 & 0.39 \\
\hline & B-R-R & 0.27 & 0.45 & 0.70 & 0.80 & 0.83 & 1.17 & 0.02 & 5.40 & 0.03 & 3.22 & 0.69 & 1.52 \\
\hline & M-B-M-M & 0.06 & 0.28 & 0.14 & 0.39 & 0.16 & 0.47 & 0.07 & 3.24 & 0.12 & 2.01 & 0.28 & 0.34 \\
\hline \multirow{3}{*}{ M-B-M-M versus } & B-R-R & 0.42 & 1.62 & 0.33 & 2.05 & 0.08 & 2.49 & 0.26 & 1.67 & 0.23 & 1.61 & 0.02 & 4.51 \\
\hline & C & 0.07 & 2.12 & 0.91 & 0.94 & 0.32 & 1.35 & 0.79 & 1.10 & 0.00 & 4.97 & 0.81 & 1.14 \\
\hline & FP & 0.00 & 6.40 & 0.48 & 1.56 & 0.00 & 5.80 & 0.02 & 3.18 & 0.00 & 2.89 & 0.02 & 9.16 \\
\hline \multirow{2}{*}{ B-R-R versus } & FP & 0.01 & 3.94 & 0.63 & 0.76 & 0.17 & 2.33 & 0.30 & 1.91 & 0.21 & 1.80 & 0.49 & 2.03 \\
\hline & $\mathrm{C}$ & 0.56 & 1.31 & 0.12 & 0.46 & 0.29 & 0.54 & 0.42 & 0.66 & 0.01 & 3.10 & 0.03 & 0.25 \\
\hline $\mathrm{C}$ versus & FP & 0.00 & 3.02 & 0.14 & 1.66 & 0.00 & 4.31 & 0.05 & 2.90 & 0.19 & 0.58 & 0.03 & 8.02 \\
\hline
\end{tabular}
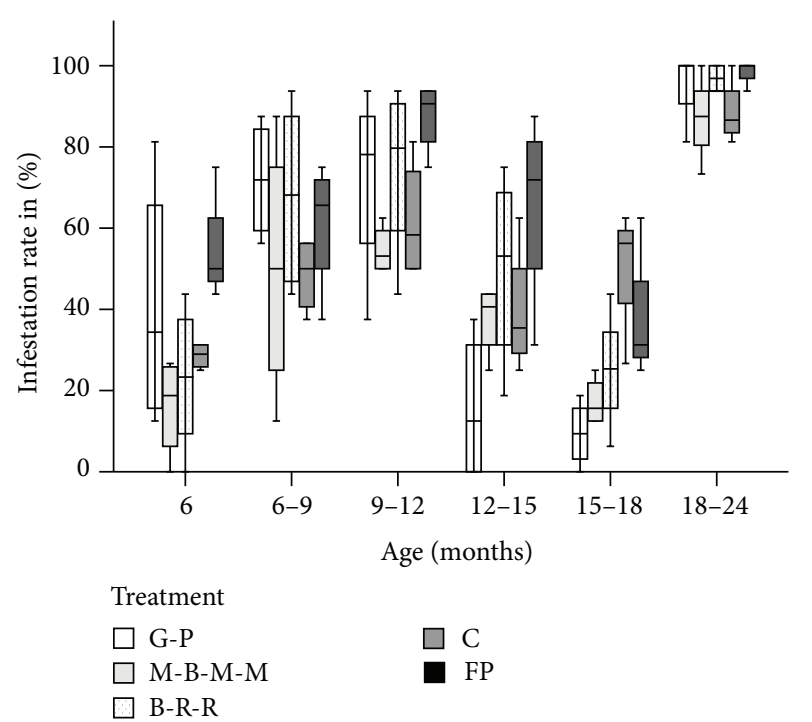

FIgURE 2: Infestation rate of $C$. odorata trees with $H$. grandella per plot, displayed by treatment and observation period ( $N$ per treatment $=4$ ). For abbreviations see Table 1 .

pest management (after the end of the 24 month observation period), the infestation rate per plot had climbed again to $100 \%$, revealing the importance of a continuous monitoring interval of 3 months or less.

Prediction of infestation probability was significantly improved by the inclusion of treatment effects during all time periods (Likelihood-Ratio-Test between intercept only model and full model Likelihood-Ratio-Chi-Square $=10.588$ (18-24 months) to 37.502 (12-15 months), $\mathrm{df}=4, P \leq 0.032$; test for treatment effect; Wald-Chi-Square $=9.915$ (15-18 months) to 35.875 (15-18 months), $\mathrm{df}=4, P \leq 0.042$ ). Figure 2 reveals that infestation rates were particularly high in the G-P, B-R-R, and FP treatments during the first 12 months. On all of these plots, either no crop was grown or only crops less than $1 \mathrm{~m}$ in height were present during this time interval (see Table 1). In contrast, mean infestation rate of trees in dense maize and cassava fields tended to be lower. For instance, between 9 and 12 months an average of $87 \%$ $( \pm 8 \%)$ of trees were attacked by $H$. grandella on the four pure forest plantation plots (FP), but only $55 \%( \pm 6 \%)$ in the maize fields (M-B-M-M treatment) and 62\% $( \pm 15 \%)$ in the cassava fields ( $\mathrm{C}$ treatment). These differences were highly significant $(P \leq 0.001$, see Table 3$)$. With increasing height of the pigeon pea shrubs (sown after 9 months), infestation rates decreased considerably. Between 12 and 18 months, when the shrubs had reached their final height of up to $3 \mathrm{~m}$, in two of the four plots assigned to the G-P treatment, no single tree was affected by $H$. grandella. Between 12 and 15 months, the risk of a $C$. odorata tree being attacked by the moth was 10 times higher on the pure forest plantation plots compared to the pigeon pea plots $(\operatorname{Exp}(\beta)=10.3 ; 95 \%$ Wald confidence interval 2.27-47.6; $P=0.002$, see Table 3 ) and 3 times higher compared to the maize and cassava plots (M-B-M-M versus FP: $\operatorname{Exp}(\beta)=3.18,95 \%$ Wald confidence interval 1.212-8.354, $P=0.02 ; \mathrm{C}$ versus $\mathrm{FP}: \operatorname{Exp}(\beta)=$ $2.9,95 \%$ Wald confidence interval 0.986-8.540). The same effect was observed in the subsequent time period (15-18 months), infestation rates of trees in former cassava plots (cassava was harvested after 12 months in the $\mathrm{C}$ treatment), in rice (B-R-R treatment), and pure forest plantation plots (FP treatment) were significantly higher than in pigeon pea plots (G-P treatment) $(P<0.001 ; P=0.033$ and 0.001 , resp.). High infestation rates led to multiple adventitious shoot formations, resulting in trees with bad stem quality. Accordingly, the lowest percentage of forked or multiple-stemmed trees was observed in the G-P treatment $(19 \% \pm 13)$, and the highest percentage in the FP plots, in which $58 \%$ of trees were badly shaped ( $P \leq 0.001$ between these treatments) (see Table 2 ). 
The odds for bad quality were significantly higher in the FP plots compared to the G-P $(\operatorname{Exp}(\beta)=5.95,95 \%$ Wald confidence interval $=2.2-16.1), \mathrm{M}-\mathrm{B}-\mathrm{M}-\mathrm{M}(\operatorname{Exp}(\beta)=4.8$, $95 \%$ Wald confidence interval $=2.0-11.5)$, and $\mathrm{C}$ treatment $(\operatorname{Exp}(\beta)=2.8,95 \%$ Wald confidence interval $=1.11-7.4)$. In the B-R-R treatment the probability of occurrence of bad quality trees was 3.4 times higher compared to the M-B-M$M$ treatment (95\% Wald confidence interval $=1.7-7.2$ ) and 4.3 times higher compared to the G-P treatment (95\% Wald confidence interval $=1.8-10.3)$.

\section{Discussion}

The overall performance of $C$. odorata observed in this study fits well to growth data from other trials of the same age. In Panama, mean heights of 0.5 to $2.2 \mathrm{~m}$ and mean basal diameters of 3 to $7.5 \mathrm{~cm}$ after two years have been reported $[16,47-49]$. A wide range of survival rates for C. odorata can be found in other studies, which are, however, all below the high rates observed here $[6,47,50,51]$ with the exception of the study by von Breugel et al. [48] which looked at a variety of sites and also found survival rates of up to $90 \%$. Due to high mortality rates, Plath et al. [47] suggested C. odorata might best be planted at sites with well-drained soils. This was not supported by our study, as the high clay content of the present soils, which tended to be waterlogged during the rainy season, did not seem to adversely affect tree survival. However, we did find that a planting position in a relative depression negatively affected tree growth performance. But, of the few trees that died during the first two years, only $40 \%$ had a planting position in a potentially waterlogged microsite. Nevertheless small-scale site conditions should be taken into account during planting.

The overall high survival rates that we observed despite the high rates of infestation also support observations of other authors that attacks by $H$. grandella usually do not cause tree death but rather lead to a reduction in growth performance and timber quality $[10,14,15]$. With the exception of one, all 320 trees were attacked at least once by $H$. grandella during the 2-year observation period, supporting the accepted view that $C$. odorata is highly susceptible to $H$. grandella in commercial reforestation projects [52-54]. However, the present study shows that infestation rates can be significantly reduced when intercropping young tree seedlings with agricultural crops as is traditionally carried out in the Taungya system. Crops that reach the same height as tree seedlings or tower above them, such as maize, cassava, and pigeon pea, seem to be especially appropriate. Height growth performance and pest damage were strongly connected, as the infested, mostly apical branches were either cut or died off. However, the magnitude of induced height increment cannot be attributed to reduced pest infestation alone. This is supported by the diameter growth rates observed, that also tended to be higher in the agroforestry treatments compared to the control plots. Factors contributing to improved growth performance might include competition for light, in the case of height increment, along with additional positive effects of crops, such as the shading out of competing grasses, reduction of soil compaction by their roots, improved nutrient input from their foliage, and the nitrogen-fixing ability of C. cajan. It is known that taller trees with multiple shoots are affected less by shoot borers $[12,55]$. Inducing rapid early growth by intercropping can therefore be an effective silvicultural measure to help reduce damages by $H$. grandella. This might also have a clear economic advantage, as frequent monitoring and manual cutting of infested parts are cost intensive. The clear increase of infestation between 18 and 24 months when monitoring frequency was reduced and seems to indicate the necessity for a three-month monitoring interval during the first two years. Therefore, if the time period in which $H$. grandella can cause serious damage to the tree can be shortened by encouraging faster initial growth, costs can be reduced considerably.

Lateral shade also significantly improved quality of $C$. odorata stems. Although future development cannot be reliably predicted from an observation period of only two years, results during this period can certainly be interpreted as a first indicator. Both effects-improved growth performance and timber quality of $C$. odorata-have also been reported from other agroforestry systems which included other shrubby species, such as coffee $[17,18]$ and cacao [19], and the positive effect has been shown to increase with lateral competition [6]. This finding is supported by the present study. The effect was highest in maize fields during the first three months after plantation establishment and in the pigeon pea fields when the shrubs had reached their final height and crown radius. In contrast, in the cassava fields, where competition was lower due to both higher planting losses and the rather open canopy structure of the shrubs, infestation was also reduced, but the effect of induced height growth was not observed. Accordingly, height performance and infestation rate in the B-R-R rotation, where crops were smaller than trees during the entire observation period, was very similar to that observed in the control plots. Leguminous shrubs seem to be the best option for enrichment planting. Maize should be considered with caution, due to the comparably high mortality of trees observed in this treatment. In another study in Panama, leguminous companion trees in silvopastoral systems did not have an effect on the growth performance of C. odorata within the first two years [47]. One possible explanation might be that the shrub species used in this study-C. cajan-is relatively fast growing, reaching up to $3 \mathrm{~m}$ after 4 months, compared to the used leguminous trees in the cited study. Furthermore, shrubs can be planted very densely-up to $1 \times 1 \mathrm{~m}$-rapidly shading out competing grasses within 3 months, and thus considerably reducing maintenance costs of forest plantations [56]. Introducing C. odorata in coffee and cacao plantations is one possible proactive measure to increase the occurrence of this endangered species in current land-use systems $[6,18]$. Moreover, from the perspective of farmers (or companies) who are interested primarily in timber production, intercropping with fast-growing staple crops, such as maize, cassava, and especially pigeon pea, might offer an interesting option as well, as they (1) offer financial returns within one year, (2) are easy to sell, (3) can be introduced in common plantation designs, (4) do not require professional knowledge for planting, and (5) can contribute to ensuring food security in rural areas, while simultaneously 
improving the quantity and quality of the timber produced. In the Taungya system, however, agriculture is traditionally carried out only during the first years until canopy closure, thus not producing additional income or consumables during the entire rotation period of trees.

Studies show that infestation of $C$. odorata with $H$. grandella generally decreases when the trees reach a height of around $6 \mathrm{~m}$ (e.g., [11] and references therein). It is assumed that cassava and pigeon pea can be intercropped with trees until trees have overcome the most susceptible period of plantation establishment. However, research is recommended to identify other shade-tolerant shrub species that could be planted in later stages of plantation development to serve as sources of staple foods or fodder while simultaneously reducing infestation with $H$. grandella and improving wood quality (as e.g., Borojoa patinoi, Eugenia stipitata). In larger reforestation areas, admixing of other tree species is recommended for the same system, as it might have a supplementary effect on reducing infestation $[51,57]$.

Small-scale farmers in particular might not have access to or the financial recourses to acquire pesticides, improved planting material or parasitoids. Given its simplicity and its similarity to current agricultural practices, the Taungya system might encourage farmers to integrate $C$. odorata into their farms and thus help meet demand for wood and ensure recovery of the species in its native range. Farmers in Panama already actively plant and protect trees on their farms [41, 58, 59]; however, systematic concepts to improve wood quality that meet demands of small-scale farmers are lacking. The system presented here might be suitable not only for $C$. odorata but could potentially be adapted to other species of Meliaceae (such as S. macrophylla) as well as to other valuable hardwoods, which will be investigated in further studies.

\section{Acknowledgments}

This research was funded by the German Research Foundation (DFG) (Project WE 2069/6-1), the Elite Network of Bavaria, and the program "Equal Opportunity for Women in Research and Teaching" by the Technische Universität München. Furthermore C. Paul was supported by the TUM Graduate School Thematic Graduate Center at the Technische Universität München. The authors wish to thank the Forest Finance Group for providing land and labor to the project and BARCA SA for logistic help. The authors also thank Laura Carlson for language editing.

\section{References}

[1] R. Condit, R. Pérez, and N. Daguerre, "Trees of Panama and Costa Rica," Reference Reviews, vol. 26, no. 1, p. 38, 2011.

[2] D. G. Peden, J. Okorio, and N. Wajja-Musukwe, "Commercial pole production in linear agroforestry systems," Agroforestry Systems, vol. 33, no. 2, pp. 177-186, 1996.

[3] R. M. Burns and B. H. Honkala, Silvics of North America. Volume 2: Hardwoods, vol. 654, 1990.

[4] M. Ashton and J. Hall, "Review: the ecology, silviculture, and use of tropical wet forests with special emphasis on timber rich types," in Silviculture in the Tropics, S. Günter, M. Weber, B.
Stimm, and R. Mosandl, Eds., Tropical Forestry, pp. 145-192, Springer, Berlin, Germany, 2011.

[5] J. Grogan, M. Peña-Claros, and S. Günter, "Managing natural populations of big-leaf mahogany," in Silviculture in the Tropics, S. Günter, M. Weber, B. Stimm, and R. Mosandl, Eds., Tropical Forestry, pp. 227-235, Springer, Berlin, Germany, 2011.

[6] C. Navarro, F. Montagnini, and G. Hernández, "Genetic variability of Cedrela odorata Linnaeus: results of early performance of provenances and families from Mesoamerica grown in association with coffee," Forest Ecology and Management, vol. 192, no. 2-3, pp. 217-227, 2004.

[7] M. C. Wiemann and G. B. Williamson, "Wood specific gravity gradients in tropical dry and montane rain forest trees," American Journal of Botany, vol. 76, no. 6, pp. 924-928, 1989.

[8] A. M. Eligon, A. Achong, and R. Saunders, "Moisture adsorption and desorption properties of some tropical woods," Journal of Materials Science, vol. 27, no. 13, pp. 3442-3456, 1992.

[9] J. Cordero and D. Boshier, "Árboles de Centroamérica: Un Manual para Extensionistas (Trees of Central America: A Manual for Extentionists)," 2003.

[10] A. C. Newton, P. Baker, S. Ramnarine, J. F. Mesén, and R. R. B. Leakey, "The mahogany shoot borer: prospects for control," Forest Ecology and Management, vol. 57, no. 1-4, pp. 301-328, 1993.

[11] O. S. Ohashi, W. J. M. Silva, O. Lameira, and J. Silva, "Management of Hypsipyla grandella in Swietenia macrophylla plantations in Pará and São Paulo States, Brazil," Tech. Rep., 2011.

[12] S. E. Ward, K. E. Wightman, and B. R. Santiago, "Early results from genetic trials on the growth of Spanish cedar and its susceptibility to the shoot borer moth in the Yucatan Peninsula, Mexico," Forest Ecology and Management, vol. 255, no. 2, pp. 356-364, 2008.

[13] F. Soto, L. Hilje, G. A. Mora, M. E. Aguilar, and M. Carballo, "Systemic activity of plant extracts in Cedrela odorata (Meliaceae) seedlings and their biological activity on Hypsipyla grandella (Lepidoptera: Pyralidae) larvae," Agricultural and Forest Entomology, vol. 9, no. 3, pp. 221-226, 2007.

[14] F. R. Wylie and M. R. Speight, "Insect pests in tropical forestry," 2012.

[15] J. E. Mayhew and A. C. Newton, “The silviculture of mahogany," 1998.

[16] M. Plath, K. Mody, C. Potvin, and S. Dorn, "Establishment of native tropical timber trees in monoculture and mixed-species plantations: small-scale effects on tree performance and insect herbivory," Forest Ecology and Management, vol. 261, no. 3, pp. 741-750, 2011.

[17] C. Viera and A. Pineda, "Productividad de lindero maderable de Cedrela odorata," Agronomía Mesoamericana, vol. 4, no. 1, pp. 85-92, 2004.

[18] J. Beer, R. Muschler, D. Kass, and E. Somarriba, "Shade management in coffee and cacao plantations," Agroforestry Systems, vol. 38, no. 1-3, pp. 139-164, 1998.

[19] A. Villarreal, G. Carrero, E. Omar et al., "Evaluación de rendimientos y rentabilidad de los componentes asociados Cwietenia macrophylla (caoba), Cedrela odorata (cedro) y Carica papaya (lechosa), establecidos en ensayos agroforestales en la finca ULA, estación experimental Caparo, edo. Barinas, Venezuela," Revista Forestal Latinoamericana, vol. 21(1), no. 39, pp. 85-104, 2006.

[20] M. Yamada and H. L. Gholz, "An evaluation of agroforestry systems as a rural development option for the Brazilian Amazon," Agroforestry Systems, vol. 55, no. 2, pp. 81-87, 2002. 
[21] B. Love and D. Spaner, "A survey of small-scale farmers using trees in pastures in Herrera Province, Panama," Journal of Sustainable Forestry, vol. 20, no. 3, pp. 37-65, 2005.

[22] M. C. León and C. A. Harvey, "Live fences and landscape connectivity in a neotropical agricultural landscape," Agroforestry Systems, vol. 68, no. 1, pp. 15-26, 2006.

[23] ANAM, "Guía Técnica de la Reforestación en Panamá. (Manual for the Reforestation in Panama)," 2010.

[24] D. Lamb, P. D. Erskine, and J. A. Parrotta, "Restoration of degraded tropical forest landscapes," Science, vol. 310, no. 5754, pp. 1628-1632, 2005.

[25] S. Günter, P. Gonzalez, G. Álvarez et al., "Determinants for successful reforestation of abandoned pastures in the Andes: soil conditions and vegetation cover," Forest Ecology and Management, vol. 258, no. 2, pp. 81-91, 2009.

[26] V. C. Griess and T. Knoke, "Can native tree species plantations in Panama compete with Teak plantations? An economic estimation,” New Forests, vol. 41, no. 1, pp. 13-39, 2011.

[27] P. K. R. Nair, "Classification of agroforestry systems," Agroforestry Systems, vol. 3, no. 2, pp. 97-128, 1985.

[28] D. L. M. Vieira, K. D. Holl, and F. M. Peneireiro, "Agrosuccessional restoration as a strategy to facilitate tropical forest recovery," Restoration Ecology, vol. 17, no. 4, pp. 451-459, 2009.

[29] T. Knoke, B. Calvas, N. Aguirre et al., "Can tropical farmers reconcile subsistence needs with forest conservation?" Frontiers in Ecology and the Environment, vol. 7, no. 10, pp. 548-554, 2009.

[30] L. Castro, B. Calvas, P. Hildebrandt, and T. Knoke, "Avoiding the loss of shade coffee plantations: how to derive conservation payments for risk-averse land-users," Agroforestry Systems, pp. $1-17,2012$.

[31] J. Evans and J. W. Turnbull, "Plantation forestry in the tropics. The role, silviculture, and use of planted forests for industrial, social, environmental and agroforestry purposes," 2004.

[32] C. F. Jordan, "Taungya. Forest plantations with agriculture in Southeast Asia," 1992.

[33] A. Schlönvoigt and J. Beer, "Initial growth of pioneer timber tree species in a Taungya system in the humid lowlands of Costa Rica," Agroforestry Systems, vol. 51, no. 2, pp. 97-108, 2001.

[34] B. A. Martínez and C. I. Rangel, "Comportamiento de especies tropicales bajo tres sistemas de plantación," Foresta Veracruzana, vol. 6, no. 1, pp. 45-51, 2004.

[35] P. L. Weaver, “Taungya plantings in Puerto Rico," Journal of Forestry, vol. 87, no. 3, pp. 37-41, 1989.

[36] R. Ennion, "Evaluation of four taungya permanent big-leaf mahogany plots, aged 36 to 38 years, in Belize," in Big-Leaf Mahogany, A. Lugo, J. Figueroa Colón, and M. Alayón, Eds., Ecological Studies, pp. 362-374, Springer, New York, NY, USA, 2003.

[37] ETESA (Empresa Transmisión Eléctrica Panama, S., "Historical data on mean annual temperature and rainfall in Tortí (1977-2011)," 2011, http://www.hidromet.com.pa/clima_historicos.php.

[38] N. Ahmad and A. Mermut, "Vertisols and technologies for their management," 1996.

[39] H. Moreno, Estudio geográfico y socioeconomico del corregimiento de tortí en la provincia de Panamá [M.S. thesis], Universidad de Panama, Transístmica, Panama, 2001.

[40] Y. L. Nene, S. D. Hall, and V. K. Sheila, “The pigeonpea, 1990.
[41] J. Schuchmann, A participatory survey on current integration of trees on farms and pastures within land use systems in the township of Tortí in Panama [Bachelor thesis], Technische Universität München, Munich, Germany, 2011.

[42] I. Willoughby, C. Wilcken, P. Ivey, K. O'Grady, and F. Katto, FSC Guide to Integrated Pest, Disease and Weed Management in FSC Certified Forests and Plantations, FSC Technical Series, no. 2009-001, FSC, 2009.

[43] J. H. C. Cornelissen, S. Lavorel, E. Garnier et al., "A handbook of protocols for standardised and easy measurement of plant functional traits worldwide," Australian Journal of Botany, vol. 51, no. 4, pp. 335-380, 2003.

[44] H. P. Piepho, A. Büchse, and K. Emrich, "A Hitchhiker's guide to mixed models for randomized experiments," Journal of Agronomy and Crop Science, vol. 189, no. 5, pp. 310-322, 2003.

[45] B. T. West, A. T. Gałecki, B. W. Gillespie, and K. B. Welch, "Linear mixed models. A practical guide using statistical software," 2007.

[46] R. H. Heck, S. L. Thomas, and L. N. Tabata, "Multilevel and longitudinal modeling with PASW/SPSS," 2010.

[47] M. Plath, K. Mody, C. Potvin, and S. Dorn, "Do multipurpose companion trees affect high value timber trees in a silvopastoral plantation system?" Agroforestry Systems, vol. 81, no. 1, pp. 79-92, 2011.

[48] M. von Breugel, J. S. Hall, D. J. Craven et al., "Early growth and survival of 49 tropical tree species across sites differing in soil fertility and rainfall in Panama," Forest Ecology and Management, vol. 261, no. 10, pp. 1580-1589, 2011.

[49] M. H. Wishnie, D. H. Dent, E. Mariscal et al., "Initial performance and reforestation potential of 24 tropical tree species planted across a precipitation gradient in the Republic of Panama," Forest Ecology and Management, vol. 243, no. 1, pp. 39-49, 2007.

[50] C. Potvin and N. J. Gotelli, "Biodiversity enhances individual performance but does not affect survivorship in tropical trees," Ecology Letters, vol. 11, no. 3, pp. 217-223, 2008.

[51] D. Piotto, E. Víquez, F. Montagnini, and M. Kanninen, "Pure and mixed forest plantations with native species of the dry tropics of Costa Rica: a comparison of growth and productivity," Forest Ecology and Management, vol. 190, no. 2-3, pp. 359-372, 2004.

[52] A. C. Newton, J. P. Cornelius, J. F. Mesén, E. A. Corea, and A. D. Watt, "Variation in attack by the mahogany shoot borer, Hypsipyla grandella (Lepidoptera: Pyralidae), in relation to host growth and phenology," Bulletin of Entomological Research, vol. 88, no. 3, pp. 319-326, 1998.

[53] D. R. Pérez-Salicrup and R. Esquivel, "Tree infection by Hypsipyla grandella in Swietenia macrophylla and Cedrela odorata (Meliaceae) in Mexico's southern Yucatan Peninsula," Forest Ecology and Management, vol. 255, no. 2, pp. 324-327, 2008.

[54] C. Ramírez, G. Vera, F. Carrillo, and O. S. Magana, "El cedro rojo (Cedrela odorata L.) como alternativa de reconversión en terrenos abandonados por la agricultura comercial en el sur de Tamaulipas," Agricultura Técnica En México, vol. 34, no. 2, pp. 243-250, 2008.

[55] J. Mo, M. T. Tanton, and F. L. Bygrave, “Temporal and inter-tree variations of attack by Hypsipyla robusta moore (Lepidoptera: Pyralidae) in Australian Red Cedar (Toona australis (F. Muell.) Harmes)," Forest Ecology and Management, vol. 96, no. 1-2, pp. 139-146, 1997.

[56] C. Paul, "Enriching forest plantations with understory crops: an interdisciplinary appraoch towards reforestation, food security 
and resilient production systems," in Tropentag 2012. Resilience of Agricultural Systems Against Crises, Cuvillier E, Göttingen, Germany, 2012.

[57] C. Healy, N. J. Gotelli, and C. Potvin, "Partitioning the effects of biodiversity and environmental heterogeneity for productivity and mortality in a tropical tree plantation," Journal of Ecology, vol. 96, no. 5, pp. 903-913, 2008.

[58] E. J. Garen, K. Saltonstall, M. S. Ashton, J. L. Slusser, S. Mathias, and J. S. Hall, "The tree planting and protecting culture of cattle ranchers and small-scale agriculturalists in rural Panama: opportunities for reforestation and land restoration," Forest Ecology and Management, vol. 261, no. 10, pp. 1684-1695, 2011.

[59] C. S. Simmons, R. T. Walker, and C. H. Wood, “Tree planting by small producers in the tropics: a comparative study of Brazil and Panama," Agroforestry Systems, vol. 56, no. 2, pp. 89-105, 2002. 

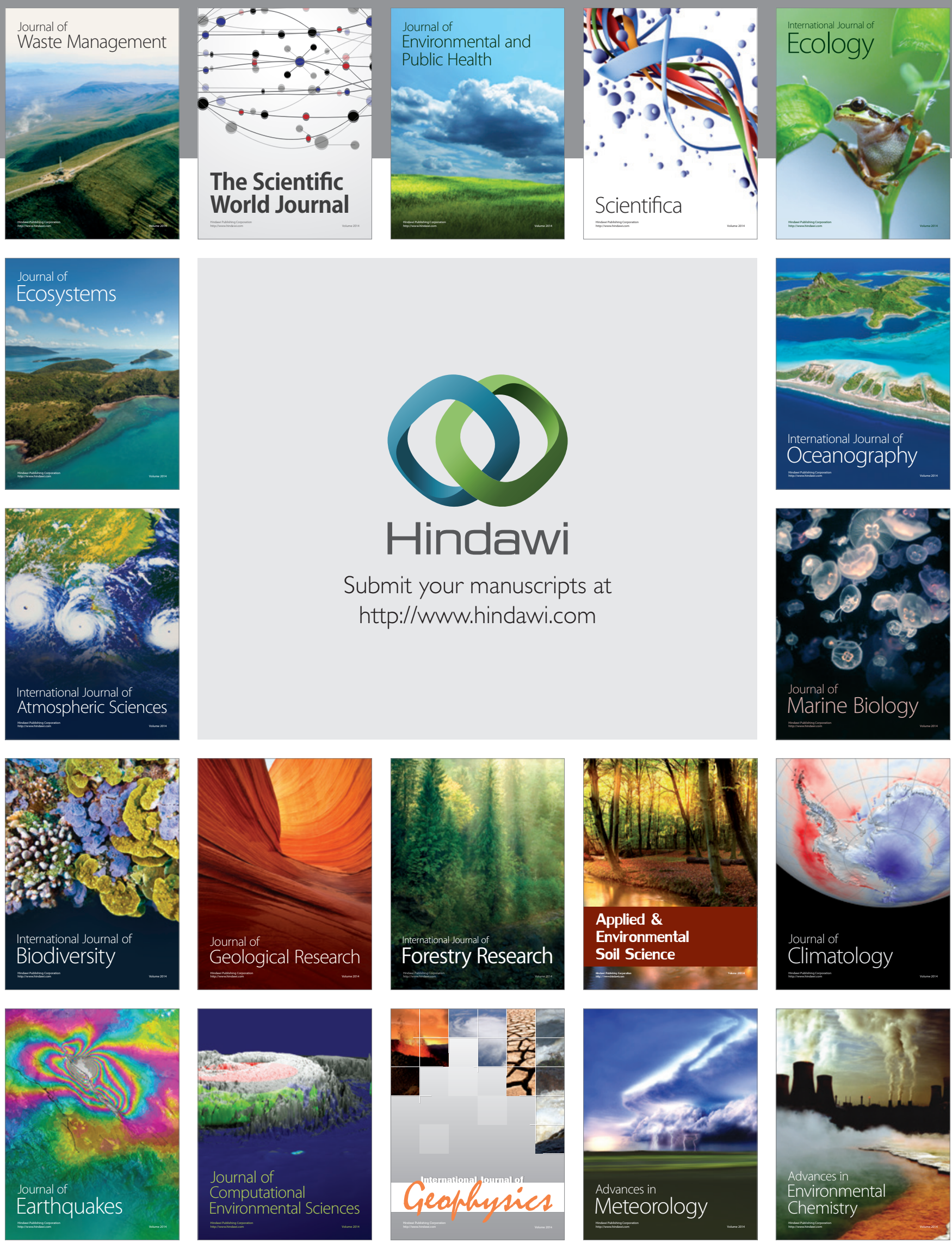